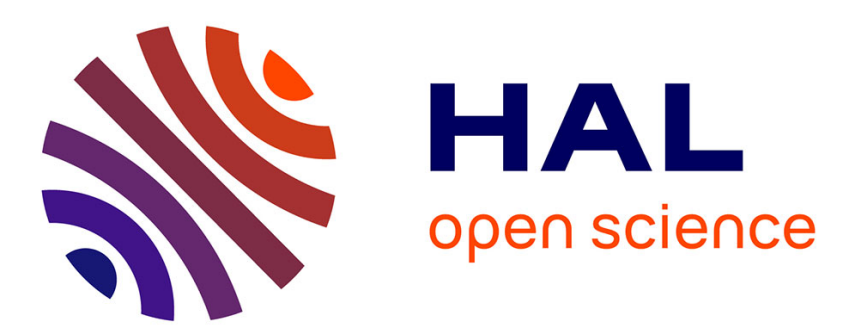

\title{
About the possibility of reprofiling a cornea by low-intensity UV-laser radiation
}

\author{
A. Razhev, I. Kornilovsky
}

\section{To cite this version:}

A. Razhev, I. Kornilovsky. About the possibility of reprofiling a cornea by low-intensity UV-laser radiation. Journal de Physique IV Proceedings, 1994, 04 (C4), pp.C4-271-C4-271. 10.1051/jp4:1994464 . jpa-00252727

\section{HAL Id: jpa-00252727 https://hal.science/jpa-00252727}

Submitted on 1 Jan 1994

HAL is a multi-disciplinary open access archive for the deposit and dissemination of scientific research documents, whether they are published or not. The documents may come from teaching and research institutions in France or abroad, or from public or private research centers.
L'archive ouverte pluridisciplinaire HAL, est destinée au dépôt et à la diffusion de documents scientifiques de niveau recherche, publiés ou non, émanant des établissements d'enseignement et de recherche français ou étrangers, des laboratoires publics ou privés. 


\section{About the possibility of reprofiling a cornea by low-intensity UV-laser radiation}

\section{A.M. RAZHEV and I.M. KORNILOVSKY}

Institute of Laser Physics of Siberian Branch of the Russian Academy of Sciences, 13/3 Acad. Lavrentyev Prosp., Novosibirsk 630090, Russia

The purpose of the work has been to investigate the possibilities of reprofliting the comea surlaoe by low-Intensity uy-radation or exoimer laser with subablation energy densities for the oomeotion of myopla, hyperopia, astigmatism and oornesl pathologies.

Investigations on 50 model sumples of some polymer materials and oornes substanoes have been oarried out. Radiations of exolmer lasers with the wavelength of 193, 223, 248, and $308 \mathrm{~nm}$ have been used. Preliminary, energy densities laying below the ablation threshold of an investigated sample had been determined.

Slaokenting of the meohanloal properties and ohange of optioal oharaoteristios of oormea substanos depending on a wevelength and energy density of low-intensity UV-Iaser radiation have been revealed.

A theoretioal prerequisite for refrative reprofiling by subablation doses of UV-Isser radiation is a dissooiation of $a \mathrm{AB}$ maoromoleoule into two eragments, $A$ and $B$, when ausurbing a photon with the energy of x-7 s.. A thenrstifnal model of this prooess is presented in the paper.

The posaibility of ohangine biomeohanioal properties of a cornea by low-Intensity Uf-laser radiation has been arnertmentaliy rhow. Fon axample, whan 10.44 wh sise deepithelfalized oomea sample was alleoted by 249 $\mathrm{nm}-\mathrm{radiation}$ with the energy density of $30 \mathrm{mj} / \mathrm{om}^{2}$ and the dose of $12 \mathrm{j}$, the deorease of strength index by $28 \%$ and. modulus of elastioity by $24 \%$ was obtained. 